\title{
ANTIBODY RESPONSE TO INFECTIONS WITH THE NEWLY CLASSIFIED TYPES OF PNEUMOCOCCI (COOPER) ${ }^{1}$
}

\author{
By ALEXANDER W. WINKLER AND MAXWELL FINLAND \\ (From the Thorndike Memorial Laboratory, Second and Fourth Medical Services \\ (Harvard), Boston City Hospital, and the Department of Medicine, \\ Harvard Medical School, Boston)
}

(Received for publication September 19, 1933)

The separation of the pneumococci previously included in Group IV into serologically specific types (1) has made possible the accurate identification of nearly all pneumococci. In this paper will be presented the result of studies on the specific antibody response of human subjects to infections associated with these newly classified types of pneumococci. Similar studies in patients with 2 important pairs of immunologically related types of pneumococci, namely, Types III and VIII and Types II and $\mathrm{V}$, have been reported in the preceding communications $(2,3)$ and only a summary of these results are included here for comparison.

The sera of 190 patients with infections associated with pneumococci other than Type I were studied. The number of patients and sera in each of 3 kinds of cases studied are listed in Table I according to the type of pneumococcus obtained. The "non-pneumonias" include patients with acute and chronic respiratory infections, but without pulmonary consolidation, and those with purulent focal infections. The methods employed were the same as those used in the previous studies (2).

\section{Agglutinins for pneumococci of the homologous type}

Agglutinins for the homologous type of pneumococcus were demonstrated in the sera of two-thirds of the patients with lobar or bronchopneumonia associated with Types II and III and with 9 of the newly classified types (see Table II). The data for the individual patients in whose sera such antibodies were demonstrated are shown in Table III and in the corresponding tables in the previous papers $(2,3)$. Also, 6 of the 22 fatal cases showed agglutinins for the homologous type in the serum before death.

The titer of the agglutinins for the newly-classified types was comparable with that found in similar patients with Types I, II and III pneumococcus pneumonia (4). Sera which agglutinated one strain of a given type also agglutinated all other strains of the same type to approximately the

1 This study was aided, in part, by a grant given in honor of Francis Weld Peabody by the Ella Sachs Plotz Foundation. 
TABLE I

Material examined

\begin{tabular}{|c|c|c|c|c|c|c|c|c|c|c|c|c|}
\hline \multirow{3}{*}{$\begin{array}{c}\text { Patients' } \\
\text { type }\end{array}$} & \multirow{3}{*}{$\begin{array}{c}\text { Num- } \\
\text { ber } \\
\text { of } \\
\text { strains }\end{array}$} & \multirow{3}{*}{$\begin{array}{c}\text { Total } \\
\text { number } \\
\text { of } \\
\text { patients }\end{array}$} & \multicolumn{4}{|c|}{ Lobar pneumonias } & \multicolumn{4}{|c|}{ Bronchopneumonias } & \multirow{2}{*}{\multicolumn{2}{|c|}{$\begin{array}{c}\text { Non-pneu- } \\
\text { monias** }\end{array}$}} \\
\hline & & & \multicolumn{2}{|c|}{ Recovered } & \multicolumn{2}{|c|}{ Died } & \multicolumn{2}{|c|}{ Recovered } & \multicolumn{2}{|c|}{ Died } & & \\
\hline & & & $\begin{array}{l}\text { Num- } \\
\text { ber } \\
\text { of pa- } \\
\text { tients }\end{array}$ & $\begin{array}{c}\text { Num- } \\
\text { ber } \\
\text { of } \\
\text { sera }\end{array}$ & $\begin{array}{l}\text { Num- } \\
\text { ber } \\
\text { of pa- } \\
\text { tients }\end{array}$ & $\begin{array}{l}\text { Num- } \\
\text { ber } \\
\text { of } \\
\text { sera }\end{array}$ & $\begin{array}{l}\text { Num- } \\
\text { ber } \\
\text { of pa- } \\
\text { tients }\end{array}$ & $\begin{array}{l}\text { Num- } \\
\text { ber } \\
\text { of } \\
\text { sera }\end{array}$ & $\begin{array}{l}\text { Num- } \\
\text { ber } \\
\text { of pa- } \\
\text { tients }\end{array}$ & $\begin{array}{l}\text { Num- } \\
\text { ber } \\
\text { of } \\
\text { sera }\end{array}$ & $\begin{array}{c}\text { Num- } \\
\text { ber } \\
\text { of pa- } \\
\text { tients }\end{array}$ & $\begin{array}{l}\text { Num- } \\
\text { ber } \\
\text { of } \\
\text { sera }\end{array}$ \\
\hline $\begin{array}{l}\text { I } \\
\text { II } \\
\text { V } \\
\text { III } \\
\text { VIII }\end{array}$ & $\begin{array}{l}1 \\
1 \\
4 \\
1 \\
8\end{array}$ & $\begin{array}{l}4 \dagger \\
11 \\
25 \\
40 \\
33\end{array}$ & $\begin{array}{r}3 \\
8 \\
19 \\
19 \\
18\end{array}$ & $\begin{array}{r}8 \\
19 \\
68 \\
44 \\
65\end{array}$ & $\begin{array}{l}- \\
2 \\
4 \\
3 \\
4\end{array}$ & $\begin{array}{r}- \\
2 \\
4 \\
5 \\
11\end{array}$ & $\begin{array}{l}- \\
0 \\
1 \\
5 \\
4\end{array}$ & $\begin{array}{r}- \\
- \\
14 \\
12\end{array}$ & $\begin{array}{l}- \\
0 \\
0 \\
3 \\
2\end{array}$ & $\begin{array}{c}- \\
- \\
3 \\
3\end{array}$ & $\begin{array}{r}1 \\
1 \\
1 \\
10 \\
6\end{array}$ & $\begin{array}{r}1 \\
1 \\
1 \\
17 \\
8\end{array}$ \\
\hline $\begin{array}{l}\text { IV } \\
\text { VII } \\
\text { IX } \\
\text { XII } \\
\text { XIV } \\
\text { XVII } \\
\text { XVIII } \\
\text { XIX }\end{array}$ & $\begin{array}{l}3 \\
4 \\
2 \\
2 \\
4 \\
2 \\
1 \\
2\end{array}$ & $\begin{array}{r}8 \\
14 \\
4 \\
4 \\
8 \\
3 \\
4 \\
7\end{array}$ & $\begin{array}{r}6 \\
10 \\
0 \\
4 \\
2 \\
2 \\
0 \\
3\end{array}$ & $\begin{array}{r}16 \\
30 \\
11 \\
6 \\
4 \\
-9\end{array}$ & $\begin{array}{l}0 \\
2 \\
1 \\
0 \\
1 \\
1 \\
0 \\
0\end{array}$ & $\begin{array}{r}- \\
4 \\
-1 \\
1 \\
1 \\
-\end{array}$ & $\begin{array}{l}0 \\
2 \\
0 \\
0 \\
2 \\
0 \\
2 \\
2\end{array}$ & $\begin{array}{r}-5 \\
\frac{-}{3} \\
\frac{6}{7}\end{array}$ & $\begin{array}{l}0 \\
0 \\
1 \\
0 \\
0 \\
0 \\
0 \\
0\end{array}$ & $\begin{array}{l}- \\
- \\
- \\
- \\
-\end{array}$ & $\begin{array}{l}2 \\
0 \\
2 \\
0 \\
3 \\
0 \\
2 \\
2\end{array}$ & $\frac{2}{\frac{3}{5}}$ \\
\hline $\begin{array}{l}\text { VI } \\
\text { X } \\
\text { XI } \\
\text { XIII } \\
\text { XV } \\
\text { XX } \\
\text { XXII } \\
\text { XXIX } \\
\text { XXXI }\end{array}$ & $\begin{array}{l}5 \\
2 \\
2 \\
1 \\
1 \\
2 \\
1 \\
1 \\
1\end{array}$ & $\begin{array}{l}8 \\
4 \\
2 \\
5 \\
1 \\
9 \\
2 \\
1 \\
1\end{array}$ & $\begin{array}{l}2 \\
0 \\
2 \\
1 \\
1 \\
5 \\
1 \\
0 \\
0\end{array}$ & $\begin{array}{l}5 \\
-5 \\
3 \\
3 \\
9 \\
2 \\
-\end{array}$ & $\begin{array}{l}2 \\
1 \\
0 \\
1 \\
0 \\
0 \\
0 \\
0 \\
0\end{array}$ & $\begin{array}{l}3 \\
4 \\
-1 \\
- \\
- \\
- \\
-\end{array}$ & $\begin{array}{l}0 \\
0 \\
0 \\
0 \\
0 \\
1 \\
1 \\
0 \\
0\end{array}$ & $\begin{array}{l}- \\
- \\
- \\
- \\
3 \\
- \\
-\end{array}$ & $\begin{array}{l}0 \\
0 \\
0 \\
0 \\
0 \\
0 \\
0 \\
0 \\
0\end{array}$ & $\begin{array}{l}- \\
- \\
- \\
- \\
-\end{array}$ & $\begin{array}{l}4 \\
3 \\
0 \\
3 \\
0 \\
3 \\
0 \\
1 \\
1\end{array}$ & $\begin{array}{l}9 \\
4 \\
3 \\
3 \\
1 \\
1\end{array}$ \\
\hline All & 51 & $194 \ddagger$ & 106 & 307 & 22 & 37 & 20 & 56 & 6 & 8 & 45 & 63 \\
\hline
\end{tabular}

* Includes acute and chronic respiratory infections without pneumonia, the pneumococcus being obtained from the sputum, and focal pneumococcic infections, where the pneumococcus was obtained from the lesion.

+ Each of these had other types of pneumococci in addition to the Type I.

$\ddagger$ Four patients are listed under 2 separate types.

same titer. In a number of instances, different methods were used to prepare the antigens and carry out the tests, but the results were practically the same in each instance.

In 2 cases, a recovered Type XII and a fatal Type XIV, the same type of pneumococcus was obtained from sputum and blood culture, but agglutinins for the homologous type could not be demonstrated in several sera. No instances were found of homologous type-specific agglutinins for the 9 types shown in the lower portion of Table I, although there were included 14 recovered pneumonia patients from whom these types were obtained. 
TABLE II

Results of agglutination tests with homologous type pneumococcus antigens in the sera of pneumonia patients $\dagger$

\begin{tabular}{|c|c|c|c|c|c|c|c|c|}
\hline \multirow{3}{*}{$\begin{array}{c}\text { Patients' } \\
\text { type* }\end{array}$} & \multicolumn{4}{|c|}{ Lobar pneumonia } & \multicolumn{4}{|c|}{ Bronchopneumonia } \\
\hline & \multicolumn{2}{|c|}{ Recovered } & \multicolumn{2}{|c|}{ Died } & \multicolumn{2}{|c|}{ Recovered } & \multicolumn{2}{|c|}{ Died } \\
\hline & $\substack{\text { Number } \\
\text { tested }}^{\text {Numberted }}$ & $\begin{array}{l}\text { Number } \\
\text { positive }\end{array}$ & $\begin{array}{c}\text { Number } \\
\text { tested }\end{array}$ & $\begin{array}{l}\text { Number } \\
\text { positive }\end{array}$ & $\underbrace{\text { Number }}_{\text {tested }}$ & $\begin{array}{l}\text { Number } \\
\text { positive }\end{array}$ & $\begin{array}{c}\text { Number } \\
\text { tested }\end{array}$ & $\begin{array}{l}\text { Number } \\
\text { positive }\end{array}$ \\
\hline II & 8 & 6 & 2 & $\mathbf{0}$ & 0 & - & 0 & - \\
\hline III & 19 & 11 & 3 & 0 & 5 & 2 & 3 & 2 \\
\hline $\mathrm{V}$ & 19 & 17 & 4 & $\mathbf{0}$ & 1 & 1 & 0 & - \\
\hline VIII & 18 & 11 & 4 & 0 & 4 & 3 & 2 & 1 \\
\hline IV & 6 & 5 & $\mathbf{0}$ & - & 0 & 一 & 0 & - \\
\hline VII & 10 & 8 & 2 & 2 & 2 & 2 & 0 & - \\
\hline XII & 4 & 1 & $\mathbf{0}$ & - & $\mathbf{0}$ & - & $\mathbf{0}$ & - \\
\hline XIV & 2 & 1 & 1 & $\mathbf{0}$ & 2 & 1 & 0 & - \\
\hline XVII & 2 & 0 & 1 & 1 & 0 & - & 0 & - \\
\hline XVIII & 0 & - & 0 & - & 2 & 1 & 0 & - \\
\hline XIX & 3 & 2 & 0 & - & 2 & 2 & 0 & - \\
\hline All & 91 & 62 & 17 & 3 & 18 & 12 & 5 & 3 \\
\hline
\end{tabular}

* Only types against which agglutinins were demonstrated in the sera of 1 or more pneumonic patients are given in this table.

t The following abbreviations and notations apply to this and subsequent tables of this paper: etc.

Pn. IV, Pn. VII, etc. $=$ Pneumococcus Type IV, Pneumococcus Type VII,

"Day" = The numbers represent the number of days after the onset of the disease.

"Agglutinins" = The numbers represent the highest dilution of serum in which floccular agglutination was observed. More than one number in these columns are recorded when different titers were obtained with different antigens or on repeated tests.

"Mouse protection" = The figures represent the highest number of lethal doses against which mice were protected.

$$
\begin{aligned}
+ & =\text { end point not made out. } \\
x & =\text { irregular survivals. } \\
- & =\text { indeterminate or test not done. }
\end{aligned}
$$

Only 2 patients without pneumonia had homologous type agglutinins. One of these had an acute upper respiratory infection and Type III and the other was a cardiac patient with chronic bronchitis and Type IX pneumococci in the sputum. Others had protective antibodies without agglutinins $(2,3)$.

\section{Agglutinins for pneumococci of heterologous types}

The serum of every patient was tested for agglutinins with Types I, II and III and usually with strains of about 15 heterologous types of 
TABLE III

Immune response to infections with the newly classified types of pneumococci (Only cases with antibodies are listed; Types V and VIII excluded)

\begin{tabular}{|c|c|c|c|c|c|c|c|c|c|}
\hline \multirow{2}{*}{$\begin{array}{c}\text { Case } \\
\text { num- } \\
\text { ber }\end{array}$} & \multirow{2}{*}{ Patient } & \multirow{2}{*}{ Age } & \multirow{2}{*}{$\begin{array}{c}\text { Pa- } \\
\text { tient's } \\
\text { type }\end{array}$} & \multicolumn{2}{|c|}{ Termination } & \multirow{2}{*}{$\begin{array}{c}\text { Day } \\
\text { of } \\
\text { serum }\end{array}$} & \multicolumn{2}{|c|}{$\begin{array}{c}\text { Homologous } \\
\text { antibodies }\end{array}$} & \multirow{2}{*}{ Remarks } \\
\hline & & & & Mode & Day & & $\begin{array}{l}\text { Agglu- } \\
\text { tinins }\end{array}$ & $\left|\begin{array}{c}\text { Pro- } \\
\text { tection }\end{array}\right|$ & \\
\hline 106 & A. F. & $\begin{array}{c}\text { years } \\
34\end{array}$ & IV & Crisis & 8 & $\begin{array}{r}7 \\
12 \\
19 \\
26\end{array}$ & $\begin{array}{c}0 \\
8-16 \\
4-16 \\
4-16\end{array}$ & $\begin{array}{c}0 \\
10^{3} \\
-10^{4} x\end{array}$ & $\begin{array}{l}\text { Blood culture nega- } \\
\text { tive 6th day. Pn. } \\
\text { IV 8th day }\end{array}$ \\
\hline 107 & D. P. & 58 & IV & Lysis & 7 & $\begin{array}{l}11 \\
18\end{array}$ & $\begin{array}{r}8 \\
4-8\end{array}$ & $\begin{array}{l}10^{4} \\
10^{4}\end{array}$ & \\
\hline 108 & J. A. & 28 & IV & Lysis & 7 & $\begin{array}{r}4 \\
16 \\
25\end{array}$ & $\begin{array}{l}8 \\
4 \\
4\end{array}$ & $\begin{array}{l}10^{3} \\
10^{3} \\
10^{3}\end{array}$ & \\
\hline 109 & M. S. & 48 & IV & Lysis & 8 & 8 & 8 & - & \\
\hline 110 & J. P. & 25 & IV & Crisis & 9 & $\begin{array}{r}7 \\
11 \\
13\end{array}$ & $\begin{array}{l}\mathbf{0} \\
\mathbf{0} \\
\mathbf{2}\end{array}$ & $\begin{array}{c}0 \\
0 \\
10^{2}\end{array}$ & . \\
\hline 111 & C. C. & 65 & VII & Lysis & $7-13$ & $\begin{array}{r}9 \\
11 \\
15 \\
24\end{array}$ & $\begin{array}{r}0 \\
0 \\
16 \\
8\end{array}$ & $\begin{array}{l}-\overline{10^{3}} \\
10^{5} \\
10^{7}\end{array}$ & $\begin{array}{l}\text { Bronchopneu- } \\
\text { monia }\end{array}$ \\
\hline 112 & A. $\mathrm{G}$. & 18 & VII & Lysis & 8 & $\begin{array}{r}9 \\
11 \\
18\end{array}$ & $\begin{array}{l}16 \\
64 \\
64\end{array}$ & $\overline{\overline{1}}$ & \\
\hline 113 & A. F. & 19 & VII & Crisis & 8 & 34 & 512 & $10^{7}$ & $\begin{array}{c}\text { Pn. I pneumonia } 3 \\
\text { years previously }\end{array}$ \\
\hline 114 & J. B. & 19 & VII & Lysis & 11 & $\begin{array}{r}9 \\
19\end{array}$ & $\begin{array}{c}0 \\
16-64\end{array}$ & $\begin{array}{l}10^{4} \\
10^{7}\end{array}$ & \\
\hline 115 & J. $Z$. & 37 & VII & Crisis & 12 & 14 & 64 & $10^{5}$ & \\
\hline 116 & S. J. & 20 & VII & Crisis & 6 & $\begin{array}{r}5 \\
10 \\
15 \\
24\end{array}$ & $\begin{array}{c}0 \\
8-16 \\
4 \\
0\end{array}$ & $\begin{array}{l}10 \\
10^{5} \\
10^{3} \\
10^{4}\end{array}$ & \\
\hline 117 & A. McD. & 43 & VII & Lysis & 7 & $\begin{array}{r}4 \\
10 \\
15 \\
29 \\
36 \\
43 \\
49\end{array}$ & $\begin{array}{c}0 \\
512 \\
256 \\
32-64 \\
32 \\
32 \\
32\end{array}$ & $\begin{array}{c}0 \\
10^{6} \\
10^{7} \\
10^{8} \\
- \\
\overline{10^{8}}\end{array}$ & \\
\hline
\end{tabular}


TABLE III (continued)

\begin{tabular}{|c|c|c|c|c|c|c|c|c|c|}
\hline \multirow{2}{*}{$\begin{array}{c}\text { Case } \\
\text { num- } \\
\text { ber }\end{array}$} & \multirow{2}{*}{ Patient } & \multirow{2}{*}{ Age } & \multirow{2}{*}{$\begin{array}{l}\text { Pa- } \\
\text { tient's } \\
\text { type }\end{array}$} & \multicolumn{2}{|c|}{ Termination } & \multirow{2}{*}{$\begin{array}{c}\text { Day } \\
\text { of } \\
\text { serum }\end{array}$} & \multicolumn{2}{|c|}{$\begin{array}{l}\text { Homologous } \\
\text { antibodies }\end{array}$} & \multirow{2}{*}{ Remarks } \\
\hline & & & & Mode & Day & & $\begin{array}{l}\text { Agglu- } \\
\text { tinins }\end{array}$ & $\begin{array}{c}\text { Pro- } \\
\text { tection }\end{array}$ & \\
\hline 118 & M. C. & $\begin{array}{c}\text { years } \\
14\end{array}$ & VII & Crisis & 9 & $\begin{array}{r}8 \\
11 \\
16 \\
22\end{array}$ & $\begin{array}{c}8 \\
8 \\
32 \\
16-32\end{array}$ & $\frac{\overline{10^{6}}}{\overline{10^{6}+}}$ & \\
\hline 119 & H. L. & 37 & VII & Crisis & 7 & 10 & 64 & $10^{6+}$ & Bronchopneumonia \\
\hline 6 & D. Van F. & 39 & VII & $\begin{array}{l}\text { Lysis. } \\
\text { Recur- } \\
\text { rence }\end{array}$ & $\begin{array}{r}23 ? \\
26-34\end{array}$ & $\begin{array}{l}25 \\
31 \\
40\end{array}$ & $\begin{array}{l}0 \\
0 \\
4\end{array}$ & $\begin{array}{c}\overline{0} \\
10^{6}\end{array}$ & $\begin{array}{l}\text { (See Table of Type } \\
\text { III cases in (2)) }\end{array}$ \\
\hline 120 & P. W. & 37 & VII & Lysis? & 18-28? & $\begin{array}{l}22 \\
23 \\
25 \\
43 \\
64\end{array}$ & $\begin{array}{l}\mathbf{0} \\
0 \\
0 \\
0 \\
0\end{array}$ & $\frac{10}{\frac{1}{10^{4}} x}$ & $\begin{array}{l}\text { Prolonged low- } \\
\text { grade fever }\end{array}$ \\
\hline 121 & H. P. & 54 & VII & Died & 10 & 9 & $8-16$ & $10^{4}$ & $\begin{array}{l}\text { Pseudocrisis 7th } \\
\text { day }\end{array}$ \\
\hline 122 & A. $\mathrm{McN}$. & 44 & VII & Died & 32 & $\begin{array}{r}4 \\
11 \\
15 \\
25\end{array}$ & $\begin{array}{r}0 \\
2-4 \\
16 \\
64\end{array}$ & $\begin{array}{l}10 \\
10^{4} \\
10^{6} \\
10^{7}\end{array}$ & $\begin{array}{l}\text { Pn. VII in blood } \\
\text { culture repeatedly } \\
\text { to } 28 \text { th day }\end{array}$ \\
\hline 123 & J. 0. & 44 & XII & Crisis & 8 & $\begin{array}{r}5 \\
10 \\
13\end{array}$ & $\begin{array}{l}0 \\
4 \\
8\end{array}$ & E & \\
\hline 124 & L. A. & 62 & XIV & Lysis & 14 & $\begin{array}{l}10 \\
21\end{array}$ & $\begin{array}{r}0 \\
4-8\end{array}$ & - & Bronchopneumonia \\
\hline 125 & L. C. & 50 & XIV & Crisis & 8 & $\begin{array}{l}11 \\
15\end{array}$ & $\begin{array}{r}64 \\
256\end{array}$ & - & \\
\hline 126 & J. L. & 42 & XVII & Died & 13 & 10 & 64 & 一 & \\
\hline 127 & B. McL. & 18 & XVIII & Lysis? & $5-10$ & $\begin{array}{r}7 \\
9 \\
24 \\
45 \\
60\end{array}$ & $\begin{array}{l}4 \\
4 \\
8 \\
2 \\
0\end{array}$ & $\frac{\overline{-}}{\frac{10^{3}}{10}}$ & $\begin{array}{l}\text { Paratyphoid B in- } \\
\text { fection with posi- } \\
\text { tive blood culture } \\
\text { on 6th and } 7 \text { th } \\
\text { days }\end{array}$ \\
\hline 128 & J. F. & 53 & XVIII & Crisis & 16 & 24 & 0 & 10 & Bronchopneumonia \\
\hline 129 & M. B. & 39 & $\mathbf{X I X}$ & Lysis & 7 & $\begin{array}{r}7 \\
15 \\
23 \\
30\end{array}$ & $\begin{array}{l}8 \\
0 \\
2 \\
0\end{array}$ & $\bar{z}$ & Bronchopneumonia \\
\hline
\end{tabular}


TABLE III (continued)

\begin{tabular}{|c|c|c|c|c|c|c|c|c|c|}
\hline \multirow{2}{*}{$\begin{array}{l}\text { Case } \\
\text { num- } \\
\text { ber }\end{array}$} & \multirow{2}{*}{ Patient } & \multirow{2}{*}{ Age } & \multirow{2}{*}{$\begin{array}{c}\text { Pa- } \\
\text { tient's } \\
\text { type }\end{array}$} & \multicolumn{2}{|c|}{ Termination } & \multirow{2}{*}{$\begin{array}{c}\text { Day } \\
\text { of } \\
\text { serum }\end{array}$} & \multicolumn{2}{|c|}{$\begin{array}{c}\text { Homologous } \\
\text { antibodies }\end{array}$} & \multirow{2}{*}{ Remarks } \\
\hline & & & & Mode & Day & & $\begin{array}{c}\text { Agglu- } \\
\text { tinins }\end{array}$ & $\mid \begin{array}{c}\text { Pro- } \\
\text { tection }\end{array}$ & \\
\hline 130 & E. McD. & $\begin{array}{c}\text { years } \\
26\end{array}$ & XIX & Crisis & 4 & $\begin{array}{r}3 \\
6 \\
10\end{array}$ & $\begin{array}{l}4 \\
8 \\
8\end{array}$ & - & Bronchopneumonia \\
\hline 131 & J. K. & 39 & XIX & Crisis & 8 & $\begin{array}{l}10 \\
16\end{array}$ & $\begin{array}{r}16 \\
8\end{array}$ & - & \\
\hline 132 & G. F. & 38 & XIX & Crisis & 12 & $\begin{array}{r}5 \\
8 \\
20 \\
35\end{array}$ & $\begin{array}{r}24 \\
4 \\
0 \\
0\end{array}$ & E & \\
\hline 133 & J. M. & 54 & IX & - & - & - & 8 & 一 & $\begin{array}{l}\text { Chronic bronchitis; } \\
\text { died } 3 \text { months } \\
\text { later }\end{array}$ \\
\hline
\end{tabular}

pneumococci. There were 18 patients in whom agglutinins were found for types other than those found in the sputum (Table IV). In one-half of these cases, the heterologous agglutinins may be considered to be crossagglutinations in antisera of types which, from other evidence, appear to be immunologically related. These included 8 instances of cross-agglutination between Types III and VIII and one between Types II and VI.

\section{Results of absorption tests}

A number of sera showing agglutinins for the homologous types were absorbed with strains of the same type and with heterologous types of pneumococci. In each instance, the agglutinins were successfully absorbed with pneumococci of the homologous type but were not materially affected by those of heterologous types. These results are shown in Table $\mathrm{V}$ and in the corresponding tables in the previous communications $(2,3)$.

\section{Results of mouse protection tests}

Attempts to enhance sufficiently the virulence of a number of strains of the new types of pneumococci for use in protection tests proved unsuccessful, except with Types V and VIII. Virulent strains of Types IV, VII and XVIII pneumococci, however, were obtained through the kindness of Miss Georgia Cooper. Protection tests were carried out on the sera of most of the patients with pneumonia from whom these types were 
obtained. The results of similar tests with Types III and VIII and Types II and V have already been reported $(2,3)$.

The results of the protection tests paralleled, in general, the findings of agglutinins (Table III). Occasional sera showed mouse-protection in the absence of agglutinins for the same type. The titer of antibodies was similar to that observed with the common types.

\section{Mixed infections}

In Table VI are listed 12 patients with pneumonia from whom 2 or more organisms, chiefly pneumococci, were isolated. The presence or

TABLE IV

Cases with agglutinins for heterologous type-specific pneumococci

\begin{tabular}{|c|c|c|c|c|c|c|}
\hline 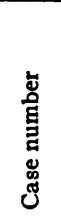 & 节 & 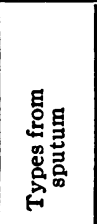 & 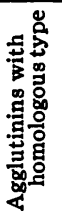 & 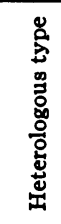 & 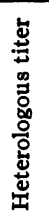 & Remarks* \\
\hline 134 & C. $\mathrm{McD}$. & $\mathrm{XV}$ & 0 & I & 4 & Protection against $10^{4}$ L.D., Pn I \\
\hline 135 & G. B. & XVII & $\mathbf{0}$ & I & 16 & $\begin{array}{l}\text { Pn. XVII in first } 2 \text { sputa, B. Friedländer } \\
\text { and no pneumococci in a later one }\end{array}$ \\
\hline 136 & H. G. & $\mathrm{XX}$ & $\mathbf{0}$ & I & 4 & $\begin{array}{l}\text { First sputum showed Hem. Strep. and no } \\
\text { pneumococci. Protection for } 10^{3} \text { L.D., } \\
\text { Pn. I }\end{array}$ \\
\hline 137 & A. C. & XXII & 0 & I & 16 & $\begin{array}{l}\text { Pn. XXII in } 2 \text { sputa. No pneumococci } \\
\text { in a third }\end{array}$ \\
\hline 27 & D. $\mathrm{McC}$. & III & 0 & V & 4 & $\begin{array}{l}\text { Fatal case. No protection against Pn. II, } \\
\text { III or V. Agglutinins (1:2 only) for } \\
\text { Pn. II and VIII. Protection } 10^{2} \text { L.D., } \\
\text { Pn. VIII. Blood culture Pn. III }\end{array}$ \\
\hline 77 & C. $\mathbf{R}$. & II & $\mathbf{0}$ & III & 4 & $\begin{array}{l}\text { Protected only } 1 \text { L.D., Pn. III. No pro- } \\
\text { tection Pn. II or V }\end{array}$ \\
\hline 50 & C. L. & VIII & 32 & III & 4 & $\begin{array}{l}\text { Protection } 10^{4} \text { L.D., Pn. III and } 10^{4} \text { L.D., } \\
\text { Pn. VIII }\end{array}$ \\
\hline 43 & R. S. & VIII & 4 & III & 4 & $\begin{array}{l}\text { Protection } 10^{3} \text { L.D., Pn. VIII; } 10^{2} \text { L.D., } \\
\text { Pn. III }\end{array}$ \\
\hline 53 & E. S. & VIII & 8 & III & 4 & $\begin{array}{l}\text { Protection } 10^{5} \text { L.D., Ph. VIII; } 10^{4} \text { L.D., } \\
\text { Pn. III }\end{array}$ \\
\hline 54 & F. H. & VIII & $\mathbf{0}$ & III & 16 & $\begin{array}{l}\text { Protection } 10^{3} \text { L.D., Pn. VIII; } 10^{5} \text { L.D., } \\
\text { Pn. III }\end{array}$ \\
\hline
\end{tabular}


TABLE IV (continued)

\begin{tabular}{|c|c|c|c|c|c|c|}
\hline 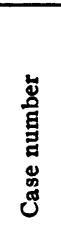 & 节 & 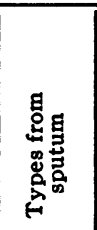 & 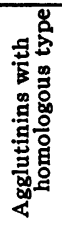 & 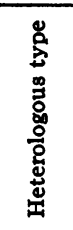 & 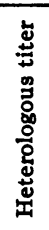 & Remark8* \\
\hline 138 & L. $\mathbf{K}$. & XII & 0 & III & 8 & $\begin{array}{l}\text { Protection } 10^{2} \text { L.D., Pn. III. Also ag- } \\
\text { glutinins }(1: 2) \text { and protection (10 } \\
\text { L.D.) Pn. VIII }\end{array}$ \\
\hline 14 & T. A. & III & 0 & V & 8 & Protection $10^{5}$ L.D., Pn. V \\
\hline 16 & J. S. & III & 0 & VIII & 4 & $\begin{array}{l}\text { No pneumococci in first sputum. Pn. III } \\
\text { in second. Protection } 10^{5} \text { L.D., Pn. } \\
\text { VIII. None for Pn. III }\end{array}$ \\
\hline 6 & D. $\operatorname{Van} F$. & $\begin{array}{l}\text { III } \\
\text { VII }\end{array}$ & $\begin{array}{l}8 \\
8\end{array}$ & VIII & 8 & $\begin{array}{l}\text { First sputum Pn. III. Pn. VII during } \\
\text { relapse. Protection } 10^{3} \text { L.D., Pn. III; } \\
10^{6} \text { L.D. for Pn. VII; } 10 \text { L.D. for Pn. } \\
\text { VIII }\end{array}$ \\
\hline 18 & M. K. & III & 2 & VIII & 16 & $\begin{array}{l}\text { Protection } 10^{3} \text { L.D., Pn. VIII; none for } \\
\text { Pn. III }\end{array}$ \\
\hline 3 & A. $S$. & III & 64 & VII & 4 & Pn. VII agglutinins in 4th month \\
\hline 73 & J. J. & II & 16 & VI & 8 & \\
\hline 9 & W. L. & $\begin{array}{l}\text { III } \\
\mathrm{X} \\
\mathrm{XVII}\end{array}$ & $\begin{array}{l}4 \\
0 \\
0\end{array}$ & VIII & 8 & $\begin{array}{l}\text { Pn. III first, Pn. X and XVII late in con- } \\
\text { valescence. Protection 10th day } 10^{4} \\
\text { L.D., Pn. III; O, Pn. VIII; } 2 \text { months } \\
\text { later O, Pn. III; } 10^{4} \text { L.D., Pn. VIII }\end{array}$ \\
\hline
\end{tabular}

* The titer is given as the greatest dilution in which floccular agglutination was observed.

L.D. = Lethal doses; Hem. Strep. = Hemolytic streptococcus.

absence of serum antibodies for each of these organisms is noted. Antibodies, if present, were usually demonstrated for only one of the organisms. The patients without pneumonia, from whose sputum more than one type of pneumococcus was obtained, are not shown, inasmuch as antibodies were not demonstrated in any of their sera.

\section{Agglutinins and mouse protection in normal subjects}

The sera of 26 hospital patients without recent infection or previous history of pneumonia and laboratory workers were tested for agglutinins with all of the types of pneumococci encountered in this investigation. Tests for mouse protection were carried out with Types I, II, III, IV, V, VII and VIII pneumococci. Agglutinins were found in only 2 in- 
TABLE V

Absorption of type-specific agglutinins with homologous and heterologous type-specific strains of pneumococci *

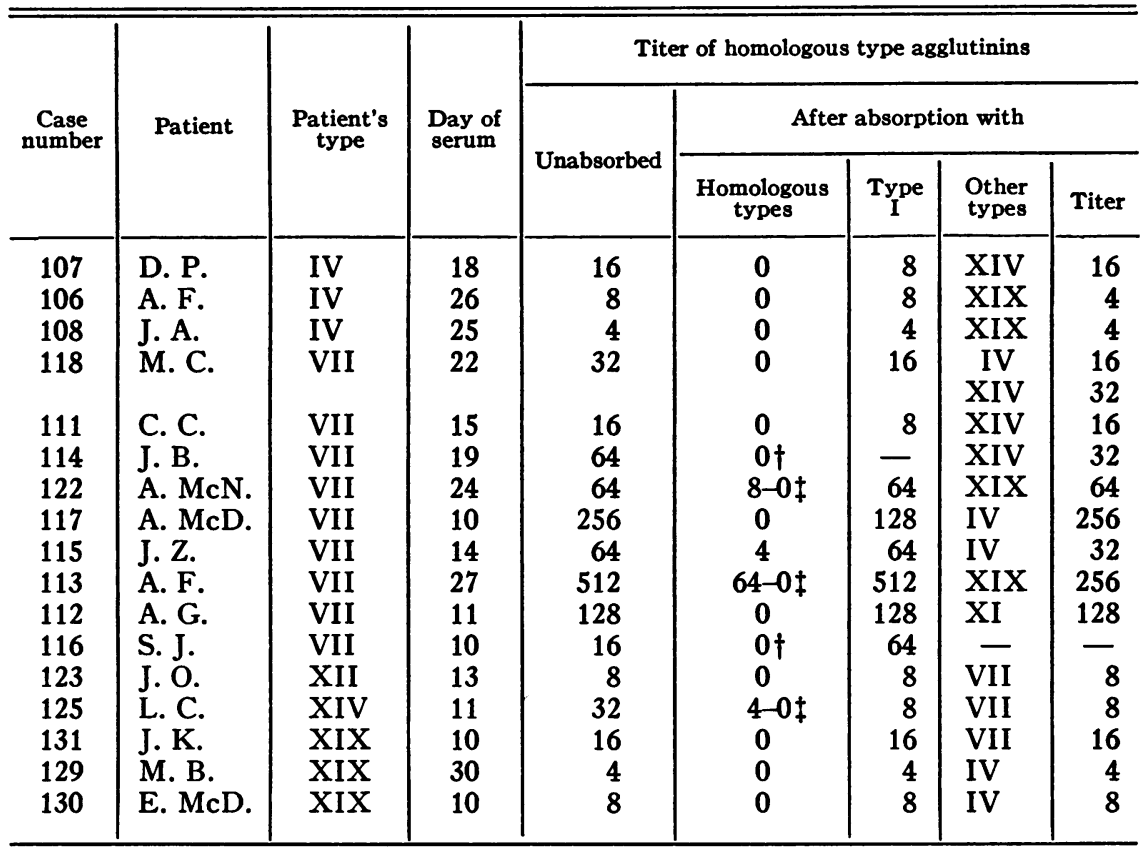

* For absorption of Types II, III, V, and VIII agglutinins see (2) and (3). + Same result with autogenous and one other strain.

$¥$ Negative result only after second absorption.

stances: one serum agglutinated Type VII and another Type XIX, each to $1: 4$ dilution only. Protection against 100 or more lethal doses of the various types occurred as follows: against Type $I$ in one serum; Type II in 2; Type III in 3; Type IV in 5; Type V in 3; Type VII in 19 and Type VIII in 3 subjects. In 6 of the subjects the serum protected against as much as 100,000 lethal doses of Type VII pneumococci. There was no correlation between the presence of protection for any one type and that against any other. These results correspond to those previously obtained with some of these types (5).

\section{DISCUSSION}

Strains of pneumococci formerly included in Group IV are found in the nose and throat of most normal individuals (6) and may be obtained, with proper methods, from some patients with pneumonia in whom the Type I or II pneumococcus is the probable invader (7). They are usually less virulent for animals than are strains of Type I and II. Their relationship to lobar pneumonia, therefore, has been doubted (7), especially 
TABLE VI

Antibodies in cases of pneumonia with mixed infections *

\begin{tabular}{|c|c|c|c|c|c|}
\hline \multirow{2}{*}{$\begin{array}{l}\text { Case } \\
\text { num- } \\
\text { ber }\end{array}$} & \multirow{2}{*}{ Patient } & \multirow{2}{*}{ Patient's types } & \multirow{2}{*}{ Days isolated } & \multicolumn{2}{|c|}{ Corresponding antibodies } \\
\hline & & & & $\begin{array}{c}\text { Present } \\
\text { or absent }\end{array}$ & Days \\
\hline 24 & J. O'B. & III, VIII & 4 & Absent & $8,10,12,23$ \\
\hline 21 & P. $\mathrm{Ci}$. & III & 11 & $\begin{array}{l}\text { Present } \\
\text { Absent }\end{array}$ & $\begin{array}{l}10,12 \\
12,17,24,31\end{array}$ \\
\hline & & $\mathrm{V}$ & 16 & Present & $12,17,24,31$ \\
\hline 90 & L. N. & XI & 3 & Absent & $4,11,31,51$ \\
\hline & $=\pi$ & $\mathrm{V}$ & 21 & Present & $11,31,51$ \\
\hline 6 & D. Van F. & $\begin{array}{l}\text { III } \\
\text { VII }\end{array}$ & $\begin{array}{l}22 \\
30\end{array}$ & $\begin{array}{l}\text { Present } \\
\text { Present }\end{array}$ & $\begin{array}{l}25,31,40 \\
40\end{array}$ \\
\hline 9 & W. L. & $\underset{\mathrm{X}}{\mathrm{III}}$ & $\begin{array}{r}5 \\
82\end{array}$ & $\begin{array}{l}\text { Present } \\
\text { Absent }\end{array}$ & $\begin{array}{l}3,12 \\
3,12,83,94\end{array}$ \\
\hline 58 & $R_{T}$ & XVII & 86 & Absent & $3,12,83,94$ \\
\hline 30 & & XVIII & 12 & Absent & $7,9,15,27$ \\
\hline 109 & M. S. & $\begin{array}{l}\text { IV } \\
\text { B. mucosus capsulatus, Type } A\end{array}$ & $\begin{array}{l}1 \\
1\end{array}$ & $\begin{array}{l}\text { Present } \\
\text { Absent }\end{array}$ & \\
\hline 127 & B. McL. $\$$ & $\begin{array}{c}\text { XVIII } \\
\text { B. paratyphosus } B\end{array}$ & $6, \quad 7$ (B.C.) & $\begin{array}{l}\text { Present } \\
\text { Present }\end{array}$ & $\begin{array}{l}7,9 \\
7,9,24,45, \\
60\end{array}$ \\
\hline 139 & H. D. & $\underset{\mathrm{IX}}{\mathrm{XIX}}$ & $\begin{array}{r}6,8 \\
6 \\
8\end{array}$ & $\begin{array}{l}\text { Absent } \\
\text { Absent } \\
\text { Present }\end{array}$ & $\begin{array}{l}7,10,18 \\
7,10,18 \\
7,10,18\end{array}$ \\
\hline 140 & G. O.\| & $\begin{array}{l}\mathbf{X} \\
\mathbf{I}\end{array}$ & $\begin{array}{l}5,11 \\
8,13 \text { (B.C.) }\end{array}$ & $\begin{array}{l}\text { Absent } \\
\text { Absent }\end{array}$ & $\begin{array}{l}5,9,10,12 \\
5,9,10,12\end{array}$ \\
\hline 141 & C. $\mathbf{R}$. & $\underset{I}{X X}$ & $\begin{array}{r}6 \\
15\end{array}$ & Absent & $\begin{array}{l}16,24,32 \\
16,24,32\end{array}$ \\
\hline 62 & E. H.ף & $\begin{array}{c}\text { VIII } \\
\text { Strep. hem.; Staph. aur. }\end{array}$ & 10 (P.M.)* & Present & $\begin{array}{l}9 \\
\text { No tests }\end{array}$ \\
\hline
\end{tabular}

* Patients with 2 types of pneumococci or with other significant organisms. See also Table IV.

$\dagger$ (B.C.) $=$ organism from blood culture only; all others are from sputum.

$\ddagger$ Only Streptococcus viridans from sputum on 6th day. No significant organisms from sputum on 19th and 33d days.

$\S$ Only Streptococcus viridans from sputum on 6th day.

II No pneumococci from sputum on 5th day. Died 13th day.

I Agglutinins and protection for Pn. VIII absent 5th day. Blood cultures negative 5th and 9th day. Autopsy cultures: Heart's blood: Strep. hem.; lungs: Strep. hem. and Staph. aureus.

* (P.M.) = Cultured at postmortem.

in the favorable cases, since bacteremia in such cases is rare and lung punctures usually yield negative results (8).

In the present study, the sera of patients with infections associated with the newly classified types of pneumococci were tested for antibodies reactive with pneumococci of the homologous type and with most of the other types commonly encountered. The objects of these tests were (1) 
to verify the antigenic, and, therefore, also the probable etiologic relationship of the newly classified types of pneumococci to the diseases with which they are associated, (2) to determine the specificity of this relationship, (3) to determine whether, in cases where the serum fails to react with the homologous type, another pneumococcus, not recovered from the patient by the ordinary methods, was responsible for the infection, and (4) to shed some light on the significance of the finding of more than one type in the same patient.

The results of these tests and of the absorption experiments indicate that, in most instances, these newly classified types of pneumococci are comparable to Types I and II in their antigenic relationship to the diseases in which they are found. The rarity with which Types I and II antibodies were demonstrated in these cases is worthy of note, since every serum was tested with these types. These types cannot be considered the exclusive causes of lobar pneumonia.

Protective antibodies, frequently of high titer, against some types of pneumococci, were demonstrated in many normal individuals. These findings, however, do not vitiate the results obtained in the pneumonia patients, since only the latter showed agglutinins and since the tests early in the disease were usually negative.

\section{SUMMARY AND CONCLUSIONS}

Two-thirds of the recovered pneumonia patients with 11 different types of pneumococci, including 9 of the newly classified types (Cooper), were found to have antibodies for the homologous type of pneumococcus. The results were similar in the patients with bronchopneumonia and those with lobar pneumonia. A number of fatal patients also had such antibodies late in the disease. Occasional patients with acute respiratory infections, without demonstrable pneumonia, also showed antibodies for the type of pneumococcus recovered from their sputa.

The specificity of the immune response was demonstrated by the failure, in such instances, to find antibodies for the other common types and by the specific absorption of the antibodies with pneumococci of the homologous and not the heterologous type.

A few cases were found to have antibodies against types other than the one isolated from the patient's sputum. Most of these represented crossagglutinations with related types, particularly Types III and VIII.

In the patients in whom more than one type of pneumococcus was isolated, immunity was usually present against only one of these.

These findings tend to confirm the biological identity of the newly classified types of pneumococci. They lend further support to the etiological relationship of these types to the acute pulmonary infections with which they are associated. 
The authors gratefully acknowledge the technical assistance of Miss Louise N. Batt and Miss Mary S. Carroll.

\section{BIBLIOGRAPHY}

1. Cooper, G., Rosenstein, C., Walter, A., and Peizer, L., The further separation of types among the pneumococci hitherto included in Group IV and the development of therapeutic antisera for these types. J. Exper. Med., $1932,55,531$.

2. Finland, M., and Winkler, A. W., Antibody response to infections with Type III and the related Type VIII pneumococcus. J. Clin. Invest., 1934, 13, 79.

3. Finland, M., and Winkler, A. W., Antibody response to infections with Type II and the related Type V pneumococcus. J. Clin. Invest., 1934, 13, 97.

4. See 2, Reference 10.

5. Finland, M., and Sutliff, W. D., Immunity reactions of human subjects to strains of pneumococci other than Types I, II and III. J. Exper. Med., 1933, 57, 95.

6. See 3, Reference 5 .

7. Gundel, M., Fehlerquellen bei der bakteriologischen Diagnose menschlicher Pneumokokkeninfektionen. Ztschr. Bakt. Paristenkunden, Infektionskr. I Abt., Orig., 1933, 127, 467.

8. See 2, Reference 12. 